\title{
Barrett's adenocarcinomas resemble adenocarcinomas of the gastric cardia in terms of chromosomal copy number changes, but relate to squamous cell carcinomas of the distal oesophagus with respect to the presence of high-level amplifications
}

\author{
Marjan M Weiss,' Ernst J Kuipers, ${ }^{2}$ Mario AJA Hermsen, ${ }^{3}$ Nicole CT van Grieken,' Johan Offerhaus, ${ }^{4}$ \\ Jan PA Baak, ${ }^{3}$ Stefan GM Meuwissen' and Gerrit A Meijer ${ }^{3 *}$ \\ ' Department of Gastroenterology, Vrije Universiteit Medical Centre, Amsterdam, The Netherlands \\ 2 Department of Gastroenterology and Hepatology, Erasmus University Medical Centre, Rotterdam, The Netherlands \\ 3 Department of Pathology, Vrije Universiteit Medical Centre, Amsterdam, The Netherlands \\ ${ }^{4}$ Department of Pathology, Academic Medical Centre, Amsterdam, The Netherlands
}

* Correspondence to: Gerrit A Meijer, Department of Pathology, VU University Medical Centre, PO Box 7057, 1007 MB Amsterdam, The Netherlands. E-mail: ga.meijer@vumc.nl
Received: 5 October 2001 Revised: 30 May 2002 Accepted: 27 August 2002

\begin{abstract}
Three different cancers predominantly occur at the gastro-oesophageal junction: squamous cell carcinomas of the distal oesophagus, adenocarcinomas of the distal oesophagus (Barrett's carcinomas), and adenocarcinomas of the gastric cardia. The aim of the present study was to investigate how, and to what extent, Barrett's carcinoma differs from adenocarcinoma of the gastric cardia on the one hand and squamous cell carcinoma of the distal oesophagus on the other, with respect to chromosomal aberrations and related gene expression. The present study analysed 14 squamous cell carcinomas, 24 Barrett's carcinomas, and 16 carcinomas of the gastric cardia. Comparative genomic hybridization revealed chromosomal abnormalities in all cases. Typical chromosomal aberrations for the squamous cell carcinoma type were gains at 3q and 11q13, and losses at 3p, 4q, 9p, 11q, and 13q. In contrast, typical copy number changes for both cardiac and Barrett's adenocarcinomas were gains at $2 q, 7 p$, and 13q, and losses at 17p. High-level amplification occurred in all three groups, but its frequency in the cardiac carcinomas was lower than in the other two groups. In conclusion, squamous cell carcinomas are characterized by chromosomal aberrations which are distinct from those seen in carcinomas of the gastric cardia and in Barrett's adenocarcinomas. With respect to Barrett's cancer, the chromosomal aberrations more closely reflect the adenocarcinoma phenotype than the squamous origin of the epithelium. Copyright $\subset 2002$ John Wiley \& Sons, Ltd.
\end{abstract}

Keywords: comparative genomic hybridization; chromosomal aberrations; gastric cancer; Barrett's carcinoma; squamous cell carcinoma; adenocarcinoma; HER2/neu; cyclin D1; immunohistochemistry

\section{Introduction}

Adenocarcinoma of the stomach has been the leading cause of cancer death worldwide through most of the 20th century. It now ranks second only to lung cancer, with an estimated 755500 new cases diagnosed annually around the world. The incidence of this disease has gradually decreased in many parts of the world, principally because of changes in $H$. pylori prevalence, diet, food preparation, and other environmental factors. In contrast, the number of patients with Barrett's cancer (BC) has increased markedly since the mid-1980s [1]. A third type of carcinoma occurring in this area is the squamous cell carcinoma of the distal oesophagus (eSCC). Although these three types of malignancies occur at the same anatomical site, they differ greatly with respect to their epidemiology and risk factors. The incidence of oesophageal adenocarcinoma has recently risen dramatically in Western populations, whereas the incidence of squamous cell carcinomas has remained relatively steady [2]. Reflux disease has been suggested as an aetiological factor not only in oesophageal adenocarcinoma, but also in cancer of the gastric cardia (CC) [3]. Other risk factors include smoking [4], increased fat intake [5], and obesity [6], whereas colonization with $H$. pylori has been suggested to protect against gastro-oesophageal reflux and Barrett's oesophagus [7]. For squamous cell carcinoma of the distal oesophagus, smoking and alcohol consumption are aetiological factors. The histology of adenocarcinomas of the gastric cardia and squamous cell carcinomas of the distal oesophagus matches with the original epithelium of the stomach 
and oesophagus, respectively, which are distinctly different. For Barrett's carcinomas, another situation exists. These tumours show histology that differs from that of the original epithelium, since it is preceded by a process of metaplasia, in which the squamous epithelium is replaced with metaplastic columnar epithelium.

The aim of the present study was to investigate how, and to what extent, Barrett's cancer compares with adenocarcinoma of the gastric cardia on the one hand and squamous cell carcinoma of the distal oesophagus on the other, in terms of chromosomal aberrations and related gene expression. To this end, we analysed 16 adenocarcinomas of the gastric cardia, 24 Barrett's carcinomas, and 14 squamous cell carcinomas of the distal oesophagus by comparative genomic hybridization (CGH). This technique allows the detection of chromosomal gains and losses throughout the whole genome in a single experiment, using DNA isolated from either frozen or formaldehyde-fixed, paraffin-embedded tissue [8]. In order to analyse the effect of amplifications at chromosomes 11q13 and $17 \mathrm{q} 12-21$ on the expression of genes in these regions, immunohistochemistry on tissue sections was performed with antibodies against cyclin Dl and Her2/Neu, respectively.

\section{Material and methods}

\section{Material}

A total of 54 patients with $\mathrm{CC}(n=16), \mathrm{BC}(n=24)$ or eSCC $(n=14)$, diagnosed by endoscopy with biopsy sampling and subsequently treated by partial or total gastrectomy or oesophagectomy, respectively, were included in the study. The Barrett's cancers were obtained from the Departments of Pathology of the VU University Medical Centre and the Academic Medical Centre, both in Amsterdam. All cases were selected according to strict criteria, based on macroscopic [by means of photographic images (Figure 1)] and microscopic re-evaluation. The tumours from the Academic Medical Centre were all macroscopically adenocarcinomas of the distal oesophagus, in which surrounding Barrett's mucosa could be identified on light microscopy, by the presence of specialized columnar epithelium containing goblet cells (intestinal metaplasia). In the samples from the Department of Pathology at the VU University Medical Centre, a background of intestinal metaplasia could not be demonstrated in every case on review of the slides. However, the study only included cases in which careful re-examination of the high-quality macroscopic photographs, taken of each resection specimen as a standard procedure, allowed an unambiguous classification. In this way, only cases with at least $75 \%$ of the tumour situated in either the cardia or the oesophagus were included. Clinical and patient characteristics are summarized in Table 1.

Both frozen and formaldehyde-fixed, paraffinembedded material was used in this study. Tissue blocks with the highest concentration of tumour cells were selected for DNA isolation. For each case, a tumour area of approximately $5 \times 5 \mathrm{~mm}$ containing more than $75 \%$ tumour cells was outlined on a haematoxylin and eosin (H\&E) slide, avoiding areas with a high concentration of inflammatory or other non-tumour cells. In 10-15 consecutive haematoxylinstained tissue sections of $10 \mu \mathrm{m}$ thickness, the corresponding area was scraped off with a surgical
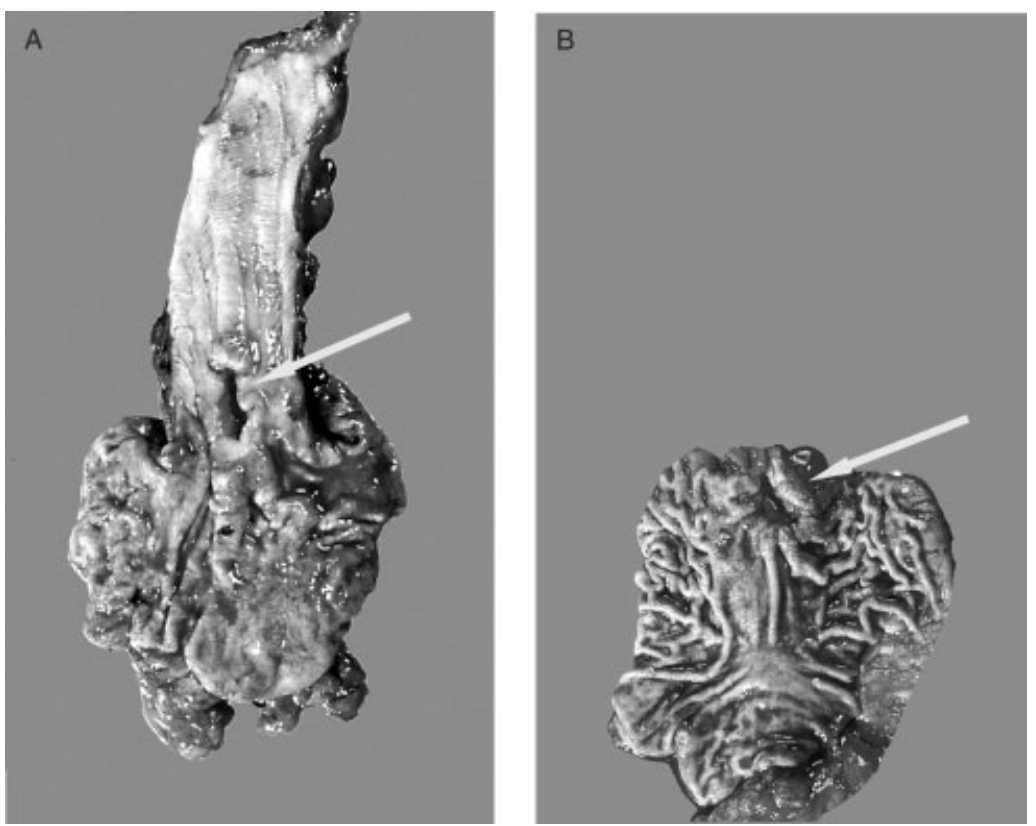

Figure I. (A) Macroscopic image of a partial oesophagogastrectomy specimen showing a tumour in the distal part of the oesophagus above the Z-line, classified as a Barrett's adenocarcinoma. (B) Macroscopic image of a partial gastrectomy specimen (without oesophagus) showing a tumour in the upper part of the stomach, classified as an adenocarcinoma of the gastric cardia 
Table I. Clinical and pathological patient characteristics

\begin{tabular}{|c|c|c|c|c|c|c|c|c|c|c|}
\hline \multirow[b]{2}{*}{ Type } & \multirow[b]{2}{*}{$\mathbf{n}$} & \multicolumn{2}{|c|}{ Sex } & \multirow[b]{2}{*}{$\begin{array}{c}\text { Mean age } \\
\text { (range), years }\end{array}$} & \multicolumn{2}{|c|}{ Stage* } & \multicolumn{3}{|c|}{$\begin{array}{c}\text { Histological } \\
\text { differentiation }\end{array}$} & \multirow[b]{2}{*}{ Laurèn type ${ }^{\dagger}$} \\
\hline & & $\begin{array}{c}\text { Male } \\
(n)\end{array}$ & $\begin{array}{c}\text { Female } \\
(n)\end{array}$ & & TI-T2 & T3-T4 & Well & Moderate & Poor & \\
\hline SCC & 14 & 6 & 8 & $64(40-75)$ & $n=6$ & $n=7$ & $n=0$ & $n=3$ & $n=11$ & - \\
\hline$B C$ & 24 & 20 & 4 & $62(28-73)$ & $n=12$ & $n=14$ & $n=4$ & $n=8$ & $n=12$ & - \\
\hline CC & 16 & 13 & 3 & $63(34-85)$ & $n=4$ & $n=12$ & $n=0$ & $n=7$ & $n=9$ & I5 intestinal I diffuse \\
\hline
\end{tabular}

* For one SCC case, the stage was not possible to judge, since this was a mucosectomy sample.

$\dagger$ For cancers of gastric cardia only.

blade. As a control, two H\&E slides were taken following the 'sandwich' method. DNA isolation with the Qiamp Tissue Kit (Qiagen GmbH, Hilden, Germany) was performed as described previously [8].

\section{Methods}

\section{Comparative genomic hybridisation (CGH)}

CGH was performed as described before [8]. Eight to 12 metaphases were recorded and analysed. This yielded relative copy number karyotypes with mean fluorescence ratios and their $95 \%$ confidence intervals (CIs) plotted along the ideograms of the corresponding chromosomes. Deviations from normal were interpreted as gains or losses when the mean fluorescence ratios were above 1.2 or below 0.8 , respectively, provided that the $95 \%$ confidence interval around the mean fluorescence ratio did not include 1.0. An event was defined as gain or loss of (part of) a chromosomal arm. Two or more distinct sub-regional copy number changes affecting the chromosomal arm were counted as separate events. Chromosomal aberrations with frequencies of $35 \%$ or higher were considered non-random changes associated with oesophageal or gastric cancer (Table 2).

\section{Immunohistochemical staining}

In order to analyse the effect of amplifications at chromosomes $11 \mathrm{q} 13$ and $17 \mathrm{q} 12-21$ on the expression of genes in these regions, immunohistochemistry on tissue sections was performed with antibodies against cyclin D1 and Her-2/Neu, respectively. One CC could not be analysed immunohistochemically because of lack of material. Immunohistochemistry for cyclin D1 was performed as described before, with minor modifications [9]. In short, $4 \mu \mathrm{m}$ sections were cut from paraffin-embedded tissue and mounted on Superfrost ${ }^{\circledR}$ Plus slides (Menzel-Gläser, Germany). The sections were deparaffinized, blocked for endogenous peroxidase activity, and antigen retrieval was performed by heating the slides in an autoclave in citrate buffer. The primary antibody against cyclin D1 (DCS-6, Neomarkers, Labvision, Fremont, CA, USA) was used in a 1:400 dilution. Slides were incubated

Table 2. Statistical evaluation of the differences of the most frequent aberrations between the squamous cell carcinomas, Barrett's adenocarcinomas, and cardiac adenocarcinomas

\begin{tabular}{|c|c|c|c|c|c|c|}
\hline \multirow[b]{2}{*}{$\begin{array}{l}\text { CGH } \\
\text { event }\end{array}$} & \multirow[b]{2}{*}{$\begin{array}{c}\text { eSCC } \\
(n=14)\end{array}$} & \multirow[b]{2}{*}{$\begin{array}{c}\text { BC } \\
(n=24)\end{array}$} & \multirow[b]{2}{*}{$\begin{array}{c}C C \\
(n=16)\end{array}$} & \multicolumn{3}{|c|}{$p$ value } \\
\hline & & & & $\begin{array}{l}\text { eSCC } \\
\text { vs CC }\end{array}$ & $\begin{array}{l}\text { eSCC } \\
\text { vs BC }\end{array}$ & $\begin{array}{l}\text { SCC vs } \\
\text { adeno }\end{array}$ \\
\hline $\mathrm{Iq}^{+}$ & $43 \%$ & $33 \%$ & $63 \%$ & NS & NS & NS \\
\hline $2 q+$ & $7 \%$ & $42 \%$ & $38 \%$ & 0.05 & 0.02 & 0.02 \\
\hline $3 p-$ & $64 \%$ & $4 \%$ & $19 \%$ & 0.01 & $<0.001$ & $<0.001$ \\
\hline $3 q+$ & $79 \%$ & $38 \%$ & $50 \%$ & NS & 0.01 & 0.02 \\
\hline $4 q-$ & $43 \%$ & $8 \%$ & $19 \%$ & NS & 0.01 & 0.02 \\
\hline $6 q+$ & $36 \%$ & $33 \%$ & $44 \%$ & NS & NS & NS \\
\hline $7 p+$ & $14 \%$ & $46 \%$ & $50 \%$ & 0.04 & 0.05 & 0.03 \\
\hline $7 q+$ & $36 \%$ & $54 \%$ & $50 \%$ & NS & NS & NS \\
\hline $8 q+$ & $50 \%$ & $54 \%$ & $56 \%$ & NS & NS & NS \\
\hline $9 p-$ & $50 \%$ & $17 \%$ & $19 \%$ & NS & 0.03 & 0.02 \\
\hline $11 \mathrm{q}-$ & $50 \%$ & $13 \%$ & $31 \%$ & NS & 0.01 & 0.03 \\
\hline $1 / q \mid 3+$ & $57 \%$ & $17 \%$ & $31 \%$ & NS & 0.01 & 0.02 \\
\hline $13 q-$ & $50 \%$ & $4 \%$ & $0 \%$ & 0.001 & 0.001 & $<0.001$ \\
\hline $13 q+$ & $14 \%$ & $42 \%$ & $44 \%$ & NS & NS & 0.06 \\
\hline $17 p-$ & $14 \%$ & $58 \%$ & $38 \%$ & NS & 0.008 & 0.02 \\
\hline $18 q-$ & $36 \%$ & $46 \%$ & $25 \%$ & NS & NS & NS \\
\hline $20 q+$ & $21 \%$ & $38 \%$ & $44 \%$ & NS & NS & NS \\
\hline
\end{tabular}

$p$ values (two-sided Pearson chi-square test) are given pairwise. The $p$ values in the last column give the differences between the squamous cell carcinomas versus the adenocarcinomas ( $B C$ and $C C$ ). 

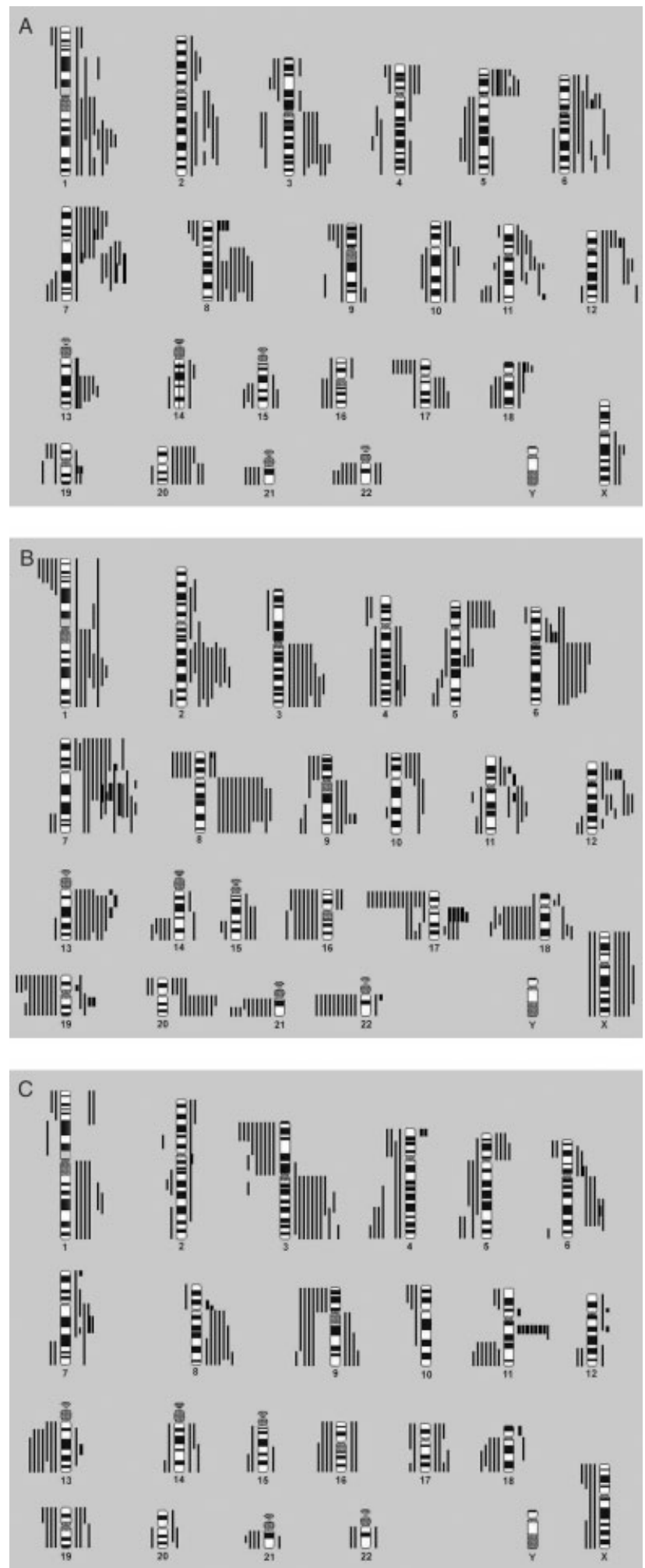

Figure 2. Overview of the genetic changes detected by $\mathrm{CGH}$ in 16 adenocarcinomas of the gastric cardia (A), 24 Barrett's carcinomas (B), and I4 squamous cell carcinomas of the distal oesophagus (C). Bars on the left of each chromosomal ideogram represent a loss, and on the right a gain of the corresponding part of the chromosome in a particular tumour. Thick lines represent amplifications

overnight with the primary antibodies at $4{ }^{\circ} \mathrm{C}$. Subsequently, slides were incubated with biotinylated rabbit anti-mouse antibody $(1: 200)$, followed by incubation with $1: 100$ streptavidin-biotinylated horseradishperoxidase complex. 3,3'-Diaminobenzidine was used as the chromogen and haematoxylin as the counterstain.

Immunohistochemistry (IHC) for $\mathrm{Her}-2 / \mathrm{Neu}$ was performed in the Ventana ES, using a monoclonal antibody [anti-C-erbB-2 (Her-2/Neu), Ventana Medical 
Systems, Inc, Tucson, AZ, USA] to $\mathrm{Her}-2 / \mathrm{Neu}$, an oncoprotein that is localized on the cell membrane, and occasionally in the cytoplasm of some neoplastic cells. The Ventana ES Immunohistochemistry Staining System is a microprocessor-controlled system for performing routine IHC. Paraffin-embedded tissue sections of $4 \mu \mathrm{m}$ were cut and deparaffinized. Antigen retrieval was done by heating the slides in an autoclave in citrate buffer. The incubation time for the primary antibody was $32 \mathrm{~min}$. A known positive ductal breast carcinoma was used as a positive control, while a negative control was obtained by omitting the primary antibodies from the staining procedure.

The intensity of nuclear and/or membranous staining, for cyclin Dl or $\mathrm{Her}-2 / \mathrm{Neu}$, respectively, was scored as negative or positive on microscopic examination by two observers.

\section{Statistical analysis}

The differences in the incidence of chromosomal aberrations per diagnostic category were pairwise tested for significance using the two-sided Pearson chisquare test. $p$ values less than 0.05 were considered significant. Significance of differences in the means of the total number of CGH events, gains, losses, and high-level gains per tumour in three diagnostic categories was tested pairwise by Student's $t$-test.

\section{Results}

Comparative genomic hybridization revealed chromosomal abnormalities in all cases. The mean number and standard deviation of events in eSSC, BC, and CC was 14 (8.3), 12 (5.8), and 14 (8.0), respectively (NS). In addition, the numbers of gains, losses, and highlevel amplifications were similar between the three groups. An overview of the CGH results in all three categories $(n=54)$ is shown in Figures 2A, 2B, and 2C. The most frequent aberrations in eSCC are, in descending order, gains at 3q (79\%), 11q13 (57\%), $8 \mathrm{q}(50 \%), 1 \mathrm{q}(43 \%), 6 \mathrm{q}(36 \%)$, and $7 \mathrm{q}(36 \%)$, and losses at 3p (64\%), 9p (50\%), 11q (50\%), 13q (50\%), $4 \mathrm{q}(43 \%)$, and $18 \mathrm{q}(36 \%)$. In BC, frequent gains were found at $7 \mathrm{q}(54 \%), 8 \mathrm{q}(54 \%), 7 \mathrm{p}(46 \%), 2 \mathrm{q}(42 \%), 13 \mathrm{q}$ (42\%), 3q (38\%), and 20q (38\%), and losses at 17p $(58 \%)$, and $18 \mathrm{q}(46 \%)$. In CC, the most frequent gains were at $1 \mathrm{q}(63 \%), 8 \mathrm{q}(56 \%), 3 \mathrm{q}(50 \%), 7 \mathrm{p}(50 \%)$, $7 \mathrm{q}(50 \%), 6 \mathrm{q}(44 \%), 13 \mathrm{q}(44 \%), 20 \mathrm{q}(44 \%)$, and $2 \mathrm{q}$ $(38 \%)$, and loss at $17 \mathrm{p}(38 \%)$ (Table 2).

The main differences in the patterns of chromosomal aberrations were found between $\mathrm{eSCC}$ on the one hand and the adenocarcinomas (BC and $\mathrm{CC}$ ) on the other. Typical chromosomal aberrations for the squamous cell carcinoma type were gains at $3 q$ and $11 \mathrm{q} 13$, and losses at 3p, 4q, 9p, 11q, and 13q. In contrast, typical copy number changes for (BC and $\mathrm{CC})$ adenocarcinomas were gains at $2 \mathrm{q}, 7 \mathrm{p}$, and 13q, and losses at 17p (Table 2). One chromosomal aberration did show a significant difference between $\mathrm{BC}$ and $\mathrm{CC}$ (gain of $4 \mathrm{p}$ ), but this gain occurred at a rather low frequency (three times in $\mathrm{CC}$; none in $\mathrm{BC}$ ).

High-level amplification occurred in all three groups, but its frequency in CC was lower than in the other two groups. From a biological perspective there was a high incidence of recurrent amplifications, although the absolute numbers were too low for reliable statistical analysis. Nevertheless, a certain specificity for diagnostic categories could be noted here (Table 3); for example, in the eSCC group, amplification of 11q13 occurred in 50\% of the cases, compared with only a single case in $\mathrm{BC}$ and none in CC. In addition, amplification of $7 \mathrm{q} 21-22$ and $17 \mathrm{q} 12-21$ occurred preferentially in BC $(25 \%$ and $21 \%$, respectively), versus $0 \%$ for these regions in CC and $7 \%$ and $0 \%$, respectively, in eSCC.

Overexpression of cyclin D1 is shown in $11 / 14$ eSCCs (79\%), 7/24 BCs (29\%), and 6/15 CCs (40\%) by immunohistochemistry (Table 4). All but one of the cases with amplification of 11q13 showed overexpression at the protein level, while in one eSCC case we detected amplification by CGH without protein overexpression. Her-2/Neu overexpression was seen in only 1/11 (7\%) eSCCs, 10/24 (42\%) BCs, and 3/15 (20\%) CCs. Of BC with protein overexpression, four cases were seen with and six without amplification. One BC with 17q12-21 amplification did not show protein overexpression. Finally, in all three CCs showing $\mathrm{Her}-2 / \mathrm{Neu}$ protein overexpression, we could not detect amplification of the chromosomal locus.

\section{Discussion}

Patients with cancer of the cardia more closely resemble those with Barrett's carcinoma than those with cancers of the distal stomach, in terms of sex and racial characteristics, frequency of reflux symptoms, and frequency of associated atrophic gastritis. Disease behaviour and survival in Barrett's and gastric cardiac cancer also appear very similar [10]. However, Barrett's cancer differs from cancers of the gastric cardia with respect to certain epidemiological parameters that could reflect independent carcinogenetic mechanisms. There is a higher proportion of males among the patients with carcinoma of the cardia. In addition, patients with cardiac cancer more frequently have a history of heavy smoking and alcohol intake, whereas those with Barrett's carcinoma are much more likely to have hiatus hernias [11]. Morphologically, Barrett's carcinoma and cardiac cancer are virtually identical, and clearly different from squamous cell carcinoma of the oesophagus, although Barrett's carcinoma arises in squamous epithelium through a phase of metaplasia.

In clinical practice, adenocarcinomas of the gastric cardia and those arising in the distal oesophagus, the Barrett's carcinomas, were in the past often classified under the single heading of adenocarcinoma 
Table 3. High-level gains and candidate genes located at these loci

\begin{tabular}{|c|c|c|c|c|}
\hline $\begin{array}{l}\text { High-level } \\
\text { gain }\end{array}$ & $\begin{array}{c}\text { eSCC } \\
(n=14)\end{array}$ & $\begin{array}{c}\text { BC } \\
(n=24)\end{array}$ & $\begin{array}{c}C C \\
(n=16)\end{array}$ & $\begin{array}{l}\text { Candidate } \\
\text { genes }\end{array}$ \\
\hline $2 q 11.2-12$ & I (7\%) & - & - & \\
\hline $4 p 16$ & $2(14 \%)$ & - & - & $\begin{array}{l}\text { Cyclin G-associated kinase } \\
\text { (GAK) } \\
\text { Fibroblast growth factor } \\
\text { receptor } 3 \text { (FGFR3) } \\
\text { Zinc finger protein I4I } \\
\text { (ZNFI4I) } \\
\text { HGF activator (HGFAC) }\end{array}$ \\
\hline $4 q 27$ & - & I (4\%) & - & Cyclin A \\
\hline $6 p 12-21.2$ & I (7\%) & $2(8 \%)$ & I (6\%) & $\begin{array}{l}\text { Vascular endothelial growth } \\
\text { factor A (VEGFA) } \\
\text { Protein-tyrosine kinase-7 } \\
\text { (PTK7) }\end{array}$ \\
\hline $6 q 22$ & I (7\%) & - & - & $\begin{array}{l}\text { MYB oncogene, ROS } \\
\text { oncogene }\end{array}$ \\
\hline $7 p 11.2-13$ & - & I (4\%) & I (6\%) & $\begin{array}{l}\text { Epidermal growth factor } \\
\text { receptor (EGFR) }\end{array}$ \\
\hline 7p22 & I (7\%) & - & - & \\
\hline $7 q 21-22$ & I (7\%) & $6(25 \%)$ & - & $\begin{array}{l}\text { Hepatocyte growth factor } \\
\text { (HGF) } \\
\text { Nerve growth } \\
\text { factor-inducible (VGF) } \\
\text { MUC 3A, II, and I2 }\end{array}$ \\
\hline $7 q 22-31$ & - & I (4\%) & $3(19 \%)$ & C-Met (HGF-receptor) \\
\hline $8 p \mid 1.2-12$ & $2(14 \%)$ & - & - & $\begin{array}{l}\text { Fibroblast growth factor } \\
\text { receptor I (FGFRI) }\end{array}$ \\
\hline $8 p 22-23$ & - & I (4\%) & $3(19 \%)$ & $\begin{array}{l}\text { Platelet-derived growth } \\
\text { factor receptor-like } \\
\text { Cathepsin B }\end{array}$ \\
\hline $9 q 31-33$ & - & I (4\%) & - & \\
\hline||$p \mid 4$ & - & I (4\%) & - & \\
\hline||$p||-13$ & I (7\%) & I (4\%) & - & $\begin{array}{l}\text { Neurite growth-promoting } \\
\text { factor-2 }\end{array}$ \\
\hline||$q \mid 3$ & $7(50 \%)$ & I (4\%) & - & $\begin{array}{l}\text { Fibroblast growth factor } 3 \\
\text { (FGF3) } \\
\text { Fibroblast growth factor } 4 \\
\text { (FGF4) } \\
\text { Cyclin DI } \\
\text { EMSI oncogene } \\
\text { PAKI }\end{array}$ \\
\hline I lq23-24 & - & - & I (6\%) & \\
\hline $12 p \mid 1.2-12$ & I (7\%) & $2(8) \%$ & - & $\begin{array}{l}\text { Retinoblastoma-binding } \\
\text { protein-2 }\end{array}$ \\
\hline$|2 q| 4$ & I (7\%) & - & - & MDM2 \\
\hline $13 q 12-13$ & - & I (4\%) & - & $\begin{array}{l}\text { Fibroblast growth factor } 9 \\
\text { (FGF9) } \\
\text { BRCA2 }\end{array}$ \\
\hline $13 q 13-14$ & - & I (4\%) & - & $\mathrm{Rb}$ \\
\hline $13 q 21-22$ & I (7\%) & I (4\%) & - & \\
\hline$|7 q| 2-2 \mid$ & - & $5(21 \%)$ & - & $\begin{array}{l}\text { HER-2-Neu (ERBB2) } \\
\text { Nerve growth factor } \\
\text { receptor (NGFR) } \\
\text { Fibroblast growth factor I I } \\
\text { (FGFI I) }\end{array}$ \\
\hline $18 p$ & I (7\%) & - & I (6\%) & YesI \\
\hline $19 p \mid 3.1$ & - & | (4\%) & - & \\
\hline $19 q \mid 3.1$ & - & $2(8 \%)$ & $2(13 \%)$ & $\begin{array}{l}\text { Transforming growth factor } \\
\text { beta I (TGFBI) } \\
\text { Cyclin E }\end{array}$ \\
\hline $22 q 11.2$ & - & I (4\%) & - & \\
\hline
\end{tabular}

of the gastro-oesophageal junction. However, international classifications do discriminate between cardiac and oesophageal adenocarcinomas. This discrimination appears to be of relevance since these tumours differ in time with respect to changes in incidence and may also differ with respect to their underlying aetiology. In clinical practice, differentiation can in most cases be made on parameters such as the location of 
Table 4. Correlation between protein expression of cyclin DI and Her-2/Neu and amplification of their chromosomal loci

\begin{tabular}{|c|c|c|c|c|c|c|c|c|c|c|c|c|c|}
\hline & & \multicolumn{3}{|c|}{$\begin{array}{c}\text { eSCC } \\
(n=14)\end{array}$} & \multicolumn{3}{|c|}{$\begin{array}{l}\text { Barrett's } \\
(n=24)\end{array}$} & \multicolumn{3}{|c|}{$\begin{array}{c}\text { Cardia } \\
(n=15)^{*}\end{array}$} & \multicolumn{3}{|c|}{ Totals } \\
\hline & & \multicolumn{3}{|c|}{$\begin{array}{c}I / q / 3 \\
\text { amplification }\end{array}$} & \multicolumn{3}{|c|}{$\begin{array}{c}\text { IIqI3 } \\
\text { amplification }\end{array}$} & \multicolumn{3}{|c|}{$\begin{array}{c}\text { IIqI3 } \\
\text { amplification }\end{array}$} & \multicolumn{3}{|c|}{$\begin{array}{c}\text { IIqI3 } \\
\text { amplification }\end{array}$} \\
\hline & & Yes & No & Totals & Yes & No & Totals & Yes & No & Totals & Yes & No & Totals \\
\hline \multirow{5}{*}{$\begin{array}{l}\text { Cyclin DI } \\
\text { overexpression }\end{array}$} & Yes & 6 & 5 & 11 & I & 6 & 7 & - & 6 & 6 & 7 & 17 & 24 \\
\hline & No & I & 2 & 3 & - & 17 & 17 & - & 9 & 9 & I & 28 & 29 \\
\hline & Totals & 7 & 7 & 14 & I & 23 & 24 & 0 & 15 & 15 & 8 & 45 & 53 \\
\hline & & \multicolumn{3}{|c|}{$\begin{array}{c}|7 q| 2-2 \mid \\
\text { amplification }\end{array}$} & \multicolumn{3}{|c|}{$\begin{array}{c}|7 q| 2-2 \mid \\
\text { amplification }\end{array}$} & \multicolumn{3}{|c|}{$\begin{array}{c}|7 q| 2-2 \mid \\
\text { amplification }\end{array}$} & \multicolumn{3}{|c|}{$\begin{array}{c}|7 q| 2-2 \mid \\
\text { amplification }\end{array}$} \\
\hline & & Yes & No & Totals & Yes & No & Totals & Yes & No & Totals & Yes & No & Totals \\
\hline \multirow{3}{*}{$\begin{array}{l}\text { Her-2/Neu } \\
\text { overexpression }\end{array}$} & Yes & - & I & I & 4 & 6 & 10 & - & 3 & 3 & 4 & 10 & 14 \\
\hline & No & - & 13 & 13 & I & 13 & 14 & - & 12 & 12 & I & 38 & 39 \\
\hline & Totals & 0 & 14 & 14 & 5 & 19 & 24 & 0 & 15 & 15 & 5 & 48 & 53 \\
\hline
\end{tabular}

* One CC case was not investigated by immunohistochemistry since tissue was no longer available.

the bulk of the tumour and the presence or absence of surrounding Barrett's mucosa. Discrimination between these two tumour types is a key issue in the present study. We therefore carefully selected Barrett's cancers according to strict criteria, in order to arrive at an unambiguous classification. Only in this way can a sound comparison be made of the chromosomal aberrations in these two types of cancer.

In the past, CGH studies have yielded indications for different patterns of chromosomal aberration between squamous cell carcinoma and adenocarcinoma, as was the case in the present study. Squamous cell carcinomas frequently show gains at 3q, 5p, 8q, 11q13, and $17 \mathrm{q}$; losses at $3 \mathrm{p}, 4 \mathrm{p}, 5 \mathrm{q}, 11 \mathrm{qter}, 13 \mathrm{q}$, and $18 \mathrm{q}$; and high-level gains at 11q13, and 3q24-qter, while adenocarcinomas frequently show gains at $1 \mathrm{q}, 8 \mathrm{q}, 13 \mathrm{q}$, and 20, and losses at 1p, 8p, 9p, and 17p [12-24]. This could indicate that different cell biological pathways need to be (de-) activated, or that the same pathway can be deregulated via different genetic changes, for tumour progression in squamous cell epithelium and columnar epithelium. An intriguing question is how tumours would behave that arise through a phase of metaplasia. The present study demonstrates that at the chromosomal level, adenocarcinomas of the gastric cardia and Barrett's carcinomas show close similarities. When comparing the Barrett's cancers to the squamous cell carcinomas of the distal oesophagus, there is little to remind us of a common origin, the epithelial stem cell.

This study is the first to compare squamous cell carcinomas, Barrett's carcinomas, and cardiac carcinomas in a single series of experiments. This is important because although CGH in itself is a straightforward technique, comparison of data from different studies may be influenced by different experimental conditions as well as by different strategies for interpreting the results. A sound comparison of chromosomal aberrations in different sets of tumours can therefore only come from a study that has been designed to eliminate these sources of bias.

We found significant differences in chromosomal aberrations between the squamous cell carcinomas and the adenocarcinomas (both Barrett's and cardiac). Gains at $11 \mathrm{q} 13$ and $3 \mathrm{q}$, and losses at $3 \mathrm{p}, 4 \mathrm{q}, 9 \mathrm{p}$, $11 q$, and $13 q$ were found more often in the squamous cell carcinomas. Gains at $2 \mathrm{q}, 7 \mathrm{p}$, and $13 \mathrm{q}$, and loss at $17 \mathrm{p}$ seemed to occur predominantly in the adenocarcinomas. Except for $4 p$ gain, we did not detect any relevant differences in gains and losses between the Barrett's carcinomas and the cardiac cancers. Loss of 14q31-32 has been suggested to have some discriminative power between cardiac and Barrett's cancer $[25,26]$, but the data of the present, larger study and the LOH study of Yanagi et al. could not confirm this [27].

However, Barrett's carcinomas shared with the squamous cell carcinomas a higher incidence of amplifications than the cardiac cancers. 11q13 is amplified in 50\% of the squamous cell carcinomas and almost never in the other two groups. In addition, the frequency of cyclin DI overexpression was also highest in the squamous cell carcinomas (79\%). Nevertheless, cyclin D1 protein overexpression was detected in $29 \%$ and $40 \%$ of the Barrett's and the cardiac carcinomas, respectively. In contrast, 17q12-q21 was only found to be amplified in the Barrett's carcinomas, while $\mathrm{Her}-2 / \mathrm{Neu}$ positivity was also highest in the Barrett's carcinomas (42\%). Interestingly, the one squamous cell carcinoma with $\mathrm{Her}-2 / \mathrm{Neu}$ overexpression appeared on re-examination also to harbour glandular differentiation and was thus classified as an adenosquamous variant. In addition, the relatively high frequency of $7 \mathrm{q}$ and $17 \mathrm{q}$ amplifications in Barrett's 

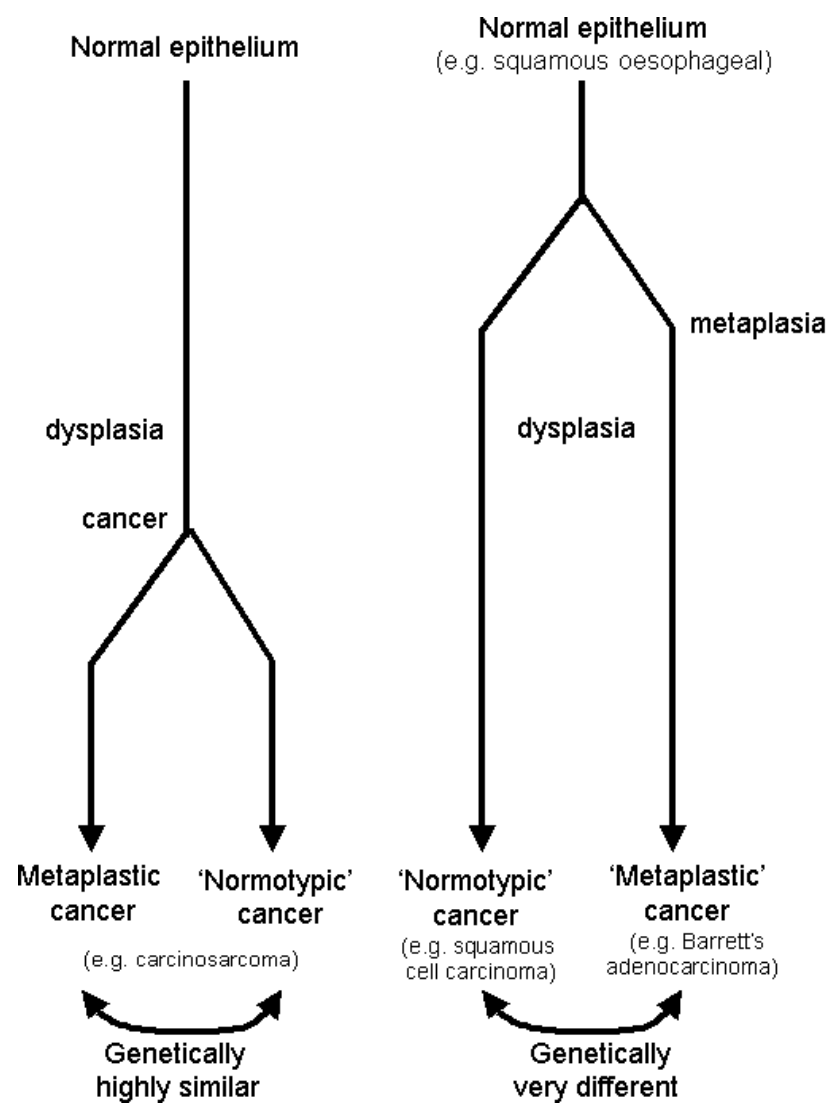

Figure 3. Relationship between genotype and phenotype in carcinogenesis (see text)

cancers compared with cardiac cancers could be an argument in favour of Barrett's cancer being a separate entity from cancers of the gastric cardia.

As to the association between gene expression and amplification, different patterns occurred. Gene amplification status matched with immunohistochemically detected protein expression for cyclin D1 in $66 \%(35 / 53)$ of cases and for Her-2/Neu in $79 \%$ (42/53). The finding of one squamous cell cancer showing 11q13 amplification without cyclin D1 overexpression, as well as one Barrett's cancer showing 17q12-21 amplification without $\mathrm{Her}-2 / \mathrm{Neu}$ overexpression, could mean that still other oncogenes at these chromosomal regions are involved in the development of these tumours (Table 3). Conversely, in $32 \%$ (17/53) of cases cyclin D1 overexpression and in $19 \%(10 / 53)$ of cases Her-2/Neu overexpression was found without amplification of the corresponding chromosomal regions, indicating that other mechanisms than gene amplification can also disrupt these biological pathways, such as amplification or mutation of upstream regulators.

The relationship between the metaplastic phenotype and genetic alterations remains intriguing from a pathogenetic point of view. When metaplastic change occurs early in the pathogenesis of cancer, as in the case of intestinal metaplasia in Barrett's oesophagus, major differences are found between 'metaplastic' and 'non-metaplastic' cancers, as shown in the present study, although some characteristics remain, such as the higher tendency to high-level amplifications. Similar findings have been made for adenocarcinomas and squamous cell carcinomas of both the uterine cervix [28] and the lung [29-31]. At the other end of the spectrum, a change in phenotype can occur at a stage when a cancer has already developed, such as adenosquamous carcinomas and carcinosarcomas. In such truly metaplastic carcinomas, the distinct components may show huge phenotypic, histological, ultrastructural, and immunohistochemical differences, but genotypically these different tumour components may show marked resemblances (Figure 3) [32]. This indicates that much of the genotype-phenotype relationship still remains to be resolved.

\section{References}

1. Blot WJ, Devesa SS, Kneller RW, Fraumeni JF Jr. Rising incidence of adenocarcinoma of the esophagus and gastric cardia. $J$ Am Med Assoc 1991; 265: 1287-1289.

2. Blot WJ, McLaughlin JK. The changing epidemiology of esophageal cancer. Semin Oncol 1999; 26: 2-8.

3. Chow WH, Finkle WD, McLaughlin JK. The relation of gastroesophageal reflux disease and its treatment to adenocarcinomas of the esophagus and gastric cardia. J Am Med Assoc 1995; 274: 474-477.

4. Gammon MD, Schoenberg JB, Ahsan H. Tobacco, alcohol, and socioeconomic status and adenocarcinomas of the esophagus and gastric cardia. J Natl Cancer Inst 1997; 89: 1277-1284.

5. Kabat GC, Ng SK, Wynder EL. Tobacco, alcohol intake, and diet in relation to adenocarcinoma of the esophagus and gastric cardia. Cancer Causes Control 1993; 4: 123-132. 
6. Chow WH, Blot WJ, Vaughan TL. Body mass index and risk of adenocarcinomas of the esophagus and gastric cardia. J Natl Cancer Inst 1998; 90: 150-155.

7. Loffeld RJ, Werdmuller BF, Kuster JG, Perez-Perez GI, Blaser MJ, Kuipers EJ. Colonization with cagA-positive Helicobacter pylori strains inversely associated with reflux esophagitis and Barrett's esophagus. Digestion 2000; 62: 95-99.

8. Weiss MM, Hermsen MA, Meijer GA, et al. Comparative genomic hybridisation. Mol Pathol 1999; 52: 243-251.

9. Mommers EC, van Diest PJ, Leonhart AM, Meijer CJ, Baak JP. Expression of proliferation and apoptosis-related proteins in usual ductal hyperplasia of the breast. Hum Pathol 1998; 29: 1539-1545.

10. Wijnhoven BP, Siersema PD, Hop WC, van Dekken H, Tilanus HW. Adenocarcinomas of the distal oesophagus and gastric cardia are one clinical entity. Rotterdam Oesophageal Tumour Study Group. Br J Surg 1999; 86: 529-535.

11. Wang HH, Antonioli DA, Goldman H. Comparative features of esophageal and gastric adenocarcinomas: recent changes in type and frequency. Hum Pathol 1986; 17: 482-487.

12. Du Plessis L, Dietzsch E, Van Gele M. Mapping of novel regions of DNA gain and loss by comparative genomic hybridization in esophageal carcinoma in the black and colored populations of South Africa. Cancer Res 1999; 59: 1877-1883.

13. Hermsen MA, Baak JP, Meijer GA, et al. Genetic analysis of 53 lymph node-negative breast carcinomas by $\mathrm{CGH}$ and relation to clinical, pathological, morphometric, and DNA cytometric prognostic factors. J Pathol 1998; 186: 356-362.

14. Heselmeyer K, Macville M, Schrock E, et al. Advanced-stage cervical carcinomas are defined by a recurrent pattern of chromosomal aberrations revealing high genetic instability and a consistent gain of chromosome arm 3q. Genes, Chromosomes Cancer 1997; 19: 233-240.

15. Iwabuchi H, Sakamoto M, Sakunaga H, et al. Genetic analysis of benign, low-grade, and high-grade ovarian tumors. Cancer Res 1995; 55: 6172-6180.

16. Moskaluk CA, Hu J, Perlman EJ. Comparative genomic hybridization of esophageal and gastroesophageal adenocarcinomas shows consensus areas of DNA gain and loss. Genes, Chromosomes Cancer 1998; 22: 305-311.

17. Pack SD, Karkera JD, Zhuang Z. Molecular cytogenetic fingerprinting of esophageal squamous cell carcinoma by comparative genomic hybridization reveals a consistent pattern of chromosomal alterations. Genes, Chromosomes Cancer 1999; 25: 160-168.

18. Pere H, Tapper J, Wahlstrom T, Knuutila S, Butzow R. Distinct chromosomal imbalances in uterine serous and endometrioid carcinomas. Cancer Res 1998; 58: 892-895.

19. Shinomiya T, Mori T, Ariyama Y, et al. Comparative genomic hybridization of squamous cell carcinoma of the esophagus: the possible involvement of the DPI gene in the 13q34 amplicon. Genes Chromosomes Cancer 1999; 24: 337-344.
20. Solinas-Toldo S, Wallrapp C, Muller-Pillasch F, Bentz M, Gress T, Lichter P. Mapping of chromosomal imbalances in pancreatic carcinoma by comparative genomic hybridization. Cancer Res 1996; 56: 3803-3807.

21. Sonoda G, Palazzo J, du Manoir S, et al. Comparative genomic hybridization detects frequent overrepresentation of chromosomal material from 3q26, 8q24, and $20 \mathrm{q} 13$ in human ovarian carcinomas. Genes, Chromosomes Cancer 1997; 20: 320-328.

22. Visakorpi T, Kallioniemi AH, Syvanen AC, et al. Genetic changes in primary and recurrent prostate cancer by comparative genomic hybridization. Cancer Res 1995; 55: 342-347.

23. Hermsen M, Guervos MA, Meijer G, et al. New chromosomal regions with high-level amplifications in squamous cell carcinomas of the larynx and pharynx, identified by comparative genomic hybridization. J Pathol 2001; 194: 177-182.

24. Meijer GA, Hermsen MAJA, Baak JPA, et al. Progression from colorectal adenoma to carcinoma is associated with nonrandom chromosomal gains as detected by comparative genomic hybridisation. J Clin Pathol 1998; 51: 901-909.

25. El Rifai W, Frierson HF Jr, Moskaluk CA, et al. Genetic differences between adenocarcinomas arising in Barrett's esophagus and gastric mucosa. Gastroenterology 2001; 121: $592-598$.

26. Dekken van H, Geelen E, Dinjens WNM. Comparative genomic hybridization of cancer of the gastroesophageal junction: deletion of 14q31-32.1 discriminates between esophageal (Barrett's) and gastric cardia adenocarcinomas. Cancer Res 1999; 59: 748-752.

27. Yanagi M, Keller G, Mueller J, et al. Comparison of loss of heterozygosity and microsatellite instability in adenocarcinomas of the distal esophagus and proximal stomach. Virchows Arch 2000; 437: 605-610.

28. Sherwood JB, Shivapurkar N, Lin WM, et al. Chromosome 4 deletions are frequent in invasive cervical cancer and differ between histologic variants. Gynecol Oncol 2000; 79: 90-96.

29. Bjorkqvist AM, Husgafvel-Pursiainen $\mathrm{K}$, Anttila S, et al. DNA gains in $3 q$ occur frequently in squamous cell carcinoma of the lung, but not in adenocarcinoma. Genes, Chromosomes Cancer 1998; 22: 79-82.

30. Petersen I, Bujard M, Petersen S, et al. Patterns of chromosomal imbalances in adenocarcinoma and squamous cell carcinoma of the lung. Cancer Res 1997; 57: 2331-2335.

31. Pei J, Balsara BR, Li W, et al. Genomic imbalances in human lung adenocarcinomas and squamous cell carcinomas. Genes Chromosomes Cancer 2001; 31: 282-287.

32. Torenbeek R, Hermsen MAJA, Meijer GA, Baak JPA, Meijer CJLM. Analysis by comparative genomic hybridization of epithelial and spindle cell components in sarcomatoid carcinoma and carcinosarcoma: histogenetic aspects. J Pathol 1999; 189: $338-343$. 